\title{
THE ELECTRICAL CONDUCTIVITY OF ELECTROLYTES FOUND IN THE SWEAT OF PATIENTS WITH FIBROCYSTIC DISEASE OF THE PANCREAS
}

\author{
BY
}

\author{
ALLAN BLOXSOM \\ From the University of Texas Postgraduate School of Medicine, Houston, Texas
}

(RECEIVED FOR PUBLICATION MARCH 31, 1959)

A search of the available medical literature reveals no study of the electrical conductivity relative to $\mathrm{NaCl}$ of the electrolytes found in the sweat of patients with fibrocystic disease of the pancreas.

\section{Methods of Study}

Simultaneous chemical and electrical conductivity studies have been done on the blood serum and sweat of five children with proven fibrocystic disease of the pancreas. The electrical conductivity tests were made by means of a modified Wheatstone bridge previously described (Bloxsom, 1959). These electrical conductivities in equivalent $\mathrm{mEq}$./1. of sodium chloride, together with the chemical analyses of the serum and sweat, are compared with the normal (Table 1).

\section{Comment}

The electrolytes in sweat are sodium, chloride, potassium and lactic acid, with sodium chloride being the major constituent (Best and Taylor, 1950). The electrical conductivities of the electrolytes present in sweat vary considerably, and in this study ranged from 15 to $60 \mathrm{mEq}$./1. solutions of sodium chloride in the normal children. In the patients with fibrocystic disease of the pancreas the electrical conductivities ranged from 80 to $150 \mathrm{mEq}$./1. solutions of sodium chloride. The electrical conductivities of normal and abnormal sweat parallel closely the electrolyte content.

Lundgren, Ramanathan, Sen Gupta and Chakravarti (1955) report that, in 25 samples of sweat obtained from 12 normal subjects, the chloride con-

TABLE 1

ELECTROLYTE CONDUCTIVITIES OF NORMAL SWEAT AND ABNORMAL SWEAT (FIBROCYSTIC DISEASE OF THE PANCREAS)

\begin{tabular}{|c|c|c|c|c|c|c|c|c|}
\hline \multirow{3}{*}{\multicolumn{4}{|c|}{ Patient }} & \multicolumn{4}{|c|}{ Chemical Values in mEq./1. } & \multirow{3}{*}{$\begin{array}{c}\text { Electrical Conductivity in } \\
\text { Equivalent mEq./l. } \mathrm{NaCl} \\
\text { Sweat }\end{array}$} \\
\hline & & & & \multicolumn{2}{|c|}{ Blood Serum } & \multicolumn{2}{|c|}{ Sweat } & \\
\hline & & & & \multirow[b]{2}{*}{$\begin{array}{c}\mathrm{Na} \\
169 \\
165 \\
144 \\
146 \\
144 \\
154\end{array}$} & $\mathrm{Cl}$ & $\mathrm{Na}$ & $\mathrm{Cl}$ & \\
\hline $\begin{array}{cl}\text { Normal: } & \\
& \text { Hill } \\
& \text { Hill } \\
& \text { Shepherd } \\
& \text { Shepherd } \\
\text { Radcliffe } & \text { Poinflick } \\
& \text { Loekin } \\
& \text { Gibson } \\
& \text { Herde } \\
\text { Lee } & \\
\text { Wagner } \\
\text { Mattfield }\end{array}$ & $\begin{array}{l}\cdots \\
\cdots \\
\ldots \\
\ldots \\
\ldots \\
\ldots \\
\cdots \\
\ldots \\
\cdots \\
\cdots\end{array}$ & $\begin{array}{l}\ldots \\
\cdots \\
\cdots \\
\cdots \\
\cdots \\
\cdots \\
\cdots \\
\cdots \\
\cdots\end{array}$ & $\begin{array}{l}. . \\
. . \\
. . \\
. \\
. \\
\therefore \\
\therefore \\
\therefore \\
. \\
.\end{array}$ & & $\begin{array}{l}109 \\
101 \\
102 \\
121 \\
112 \\
110 \\
110 \\
107 \\
103 \\
112 \\
\end{array}$ & $\begin{array}{l}48 \\
13 \\
28 \\
28 \\
31 \\
15 \\
17 \\
10 \\
26 \\
37 \\
75 \\
40 \\
\end{array}$ & $\begin{array}{r}45 \\
31 \\
14 \\
15 \\
24 \\
7 \\
15 \\
10 \\
19 \\
32 \\
56 \\
37 \\
\end{array}$ & $\begin{array}{l}60 \\
45 \\
20 \\
20 \\
38 \\
15 \\
20 \\
16 \\
25 \\
35 \\
55 \\
37\end{array}$ \\
\hline & & & & & Mean & 31 & 25 & 32 \\
\hline $\begin{array}{c}\text { Fibrocystic Disease } \\
\text { Marsh } \\
\text { Hill } \\
\text { Williams } \\
\text { Lundgren } \\
\text { Emde } \\
\end{array}$ & $\begin{array}{l}\text { of th } \\
\cdots \\
\cdots \\
\cdots \\
\cdots \\
\cdots\end{array}$ & $\begin{array}{c}\text { Panc } \\
\cdots \\
\cdots \\
\cdots \\
\cdots\end{array}$ & $\begin{array}{l}\text { s: } \\
\cdots \\
\cdots \\
\cdots \\
\cdots \\
\end{array}$ & $\begin{array}{l}144 \\
144 \\
144 \\
144 \\
139 \\
\end{array}$ & $\begin{array}{l}112 \\
110 \\
105 \\
112 \\
\end{array}$ & $\begin{array}{r}91 \\
110 \\
100 \\
144 \\
108 \\
\end{array}$ & $\begin{array}{l}105 \\
100 \\
142 \\
137 \\
117 \\
\end{array}$ & $\begin{array}{r}80 \\
100 \\
120 \\
150 \\
120\end{array}$ \\
\hline & & & & & Mean & 130 & 120 & 114 \\
\hline
\end{tabular}


centration varied from 8 to $80 \mathrm{mEq}$. $/ 1$., with the majority of readings between 25 and $40 \mathrm{mEq}$./1. and an average of $35.9 \mathrm{mEq} . / \mathrm{l}$., these readings being made on a modified Philips conductivity bridge, model GM 4249. These investigators state that the procedure for determination of the specific conductivity of small amounts of sweat was found to give results which correlated with the chloride concentration $(r=0.90)$ and the sodium concentration $(r=0.78)$. They conclude that the electrical conductivity method can therefore be used for estimation of the concentration of sodium chloride which is the major electrolyte in sweat. The main requirements in determining electrical conductivity are that such a procedure is simple and rapid, can be applied to minute volumes of sweat (less than $\frac{1}{6} \mathrm{ml}$. (Lundgren et al., 1955)) and is relatively free of error.

In this study there was no overlapping of the electrical conductivities of normal and abnormal sweat. The determination of the electrical conductivity of sweat is a simple, rapid laboratory procedure, relatively free of error.

\section{Summary}

Electrical conductivities of normal and abnormal sweat, expressed relative to standard solutions of $\mathrm{NaCl}$, parallel the concentrations of the electrolytes present and their determination constitutes a quick, simple and inexpensive, error-free laboratory procedure that can be used in the study of fibrocystic disease of the pancreas.

\section{REFERENCES}

Best, C H and Taylor, N. B. (1950). The Physiological Basis of Medical Practice, 5th ed., pp. 494-495. Williams and Wilkins

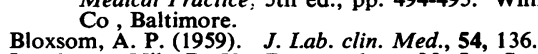

Lundgren, Nils P. V., Ramanathan, N. L., Sen Gupta, A. and Chakravarti, H.'S. (1955) Indian J. med. Res., 43, 157. 